\title{
DIRECT BEHAVIORAL CONSULTATION (DBC) UNTUK MENGURANGI PERILAKU OFF TASK
}

\author{
Evi Winingsih \\ Program Studi Bimbingan dan Konseling, Fakultas Ilmu Pendidikan, Universitas Negeri Surabaya \\ eviwiningsih@unesa.ac.id
}

\begin{abstract}
Abstrak
Tujuan penelitian adalah (1) mengurangi frekuensi perilaku off task siswa Madrasah Ibtidaiyah melalui strategi DBC, (2) mengurangi durasi perilaku off task siswa Madrasah Ibtidaiyah strategi DBC, (3) mengetahui variabel apa saja yang mempengaruhi perilaku off task siswa Madrasah Ibtidaiyah. Penelitian menggunakan single subjek design dengan model ABAB. Subjek penelitiannya tiga orang siswa yang memiliki perilaku off task tertinggi di kelas 4 MI Miftahul Ulum Kecamatan Cerme. Hasil penelitian menunjukkan bahwa perilaku off task tinggi pada kondisi baseline pertama dan kedua, menurun pada kondisi intervensi pertama dan kedua. Hal ini menandakan bahwa intervensi yang diberikan oleh guru mampu mengurangi perilaku off task siswa. Ada beberapa variabel yang memicu timbulnya perilaku off task siswa yakni: (1) teman sebangku yang mau diganggu dan dapat menggangu subjek, (2) subjek tidak mampu mengerjakan tugas yang diberikan oleh guru, (3) metode pembelajaran guru, (4) melihat atau mengetahui teman di kelas lain yang sudah beristirahat atau pulang lebih dulu, (5) guru kurang mengontrol perilaku siswa, (6) berkurangnya makna reinforcement bagi subjek, karena kurangnya variasi reinforcement yang diberikan.
\end{abstract}

Kata kunci: perilaku off task, Direct Behavioral Consultation,

\section{Abstact}

The purposes of this study were (1) reducing the frequency of off task behaviors of Madrasah Ibtidaiyah students through DBC, (2) reducing the duration of off task behaviors of Madrasah Ibtidaiyah students through DBC (3) determining the variables which influence off task behaviors Madrasah Ibtidaiyah students. This study used a single subject design with $A B A B$ model. The subjects of this research were three students having the highest off task behaviors in grade 4 of MI Miftahul Ulum, Cerme. The results showed that the off task behaviors were found high at the first and second baseline condition, while at the first and second intervention condition the off task behaviors decreased. This indicated that the intervention given by the teacher was able to reduce the off task behaviors of the students. There were several variables which triggered the students' off task behaviors: (1) bench friends who were about to be disrupted and to disturb the subjects, (2) the subjects were not able to do the tasks assigned by the teacher, (3) the teaching methods of teachers, (4) seeing or knowing friends from other classes had been resting or gone home first, (5) the teacher lacked of control on the students' behaviors, (6) the lack of reinforcement's meaning to the subjects.

Key words: Off task, Direct Behavior Consultation

\section{PENDAHULUAN}

Kurang tersedianya konselor di sekolah dasar, membuat para guru menangani masalah siswa tanpa adanya bantuan dari konselor. Proses penanganan masalah siswa yang dilaksanakan oleh para guru terkadang tidak semuanya dilaksanakan melalui prosedur yang benar, hal ini yang mengakibatkan masalah siswa tidak tertangani dengan baik.

Peran konselor dalam mengurangi perilaku off task dengan memakai pihak ketiga (guru), dapat dilakukan dengan melakukan konsultasi. Layanan konsultasi yang diberikan oleh konselor kepada guru bertujuan untuk membantu guru dalam menangani masalah siswa. Konselor membantu dengan memberikan pengetahuan dan keterampilan kepada guru untuk mengurangi perilaku off task. Proses konsultasi yang dilakukan secara behavioristik disebut DBC (Direct Behavioral Consulation). Menurut Depdiknas (2008) konselor dapat berperan serta secara produktif dijenjang sekolah dasar dengan memposisikan diri sebagai konselor kunjung yang membantu guru sekolah dasar mengatasi perilaku siswa yang menggangu (disruptive behavior), antara lain dengan pendekatan Direct Behavior Consultation. Setiap gugus sekolah dasar diangkat 2 atau 3 konselor untuk memberikan pelayanan bimbingan dan konseling. 
Observasi yang telah dilakukan, diketahui bahwa off task adalah masalah yang terjadi pada hampir semua jenjang kelas dari kelas $1 \mathrm{~s} / \mathrm{d} 6$. Hal ini terlihat dari perilaku off task yang terjadi disemua kelas yang diobservasi peneliti. Data yang diperoleh dari hasil observasi pada mata pelajaran tertentu: kelas 4 mata pelajaran fiqih terdapat $79 \%$ siswa yang melakukan off task; kelas 3 mata pelajaran bahasa daerah terdapat $82 \%$ siswa, kelas 2 mata pelajaran komputer seluruh siswa melakukan off task, sedangkan dikelas 5 mata pelajaran alquran hadist terdapat $25 \%$ siswa, dan kelas 6 mata pelajaran matematika terdapat $65 \%$ siswa melakukan perilaku off task.

Perilaku off task yang dilakukan oleh siswa MI berdasarkan hasil observasi meliputi; siswa naik bangku, keluar kelas, ngobrol dengan teman, mengajak teman bermain, mencela dan menggerutu pada guru ketika ditegur, tidur, membuka buku non pelajaran saat PBM, dan sering terjadi perdebatan antara siswa dengan guru ketika guru menegur siswa yang off task. Perilaku off task tidak hanya akan mempengaruhi akademik siswa yang melakukan perilaku off task, melainkan juga akan mempengaruhi siswa lain dalam kelas tersebut. Perilaku off task yang terjadi akan cenderung terulang setiap hari. Apabila perilaku off task tidak ditangani dengan tepat oleh guru maka perilaku ini akan menjadi sebuah masalah kronis yang akan cenderung menetap dan akan kambuh setiap saat ketika proses pembelajaran sedang berlangsung.

Pada penelitian ini, peneliti akan memilih guru dengan kriteria khusus yakni guru yang dalam PBM terjadi off task cukup tinggi. Hal ini dilakukan untuk meningkatkan keterampilan guru dalam menangani perilaku off task siswa. Ada dua orang guru yang akan berperan dalam penelitian ini. Masing-masing guru akan diberilakan layanan konsultasi dan pelatihan yang sama. Dua guru tersebut adalah guru matapelajaran PLH (Pendidikan Lingkungan Hidup) dan guru IPS (Ilmu Pengetahuan Sosial). Guru yang telah dipilih akan melaksanakan intervensi kepada siswa kelas VI yang melakukan off task khususnya subjek penelitian yang telah ditentukan sebelumnya. Mengacu pada latar belakang masalah yang telah dijelaskan di atas maka peneliti bermaksud untuk mengadakan penelitian untuk mengurangi perilaku off task siswa MI secara behavioristik melalui DBC. Tujuan penelitian ini adalah untuk memngurangi perilaku off task dari segi frekuensi dan durasi, serta mencari tahu variable apa saja yang berpegaruh pada perilaku off task.

Ada dua variable dalam penelitian ini yakni; DBC dan perilaku off task. Variabel pertama adalah DBC. DBC merupakan pendekatan yang digunakan oleh peneliti dalam melakukan intervensi perilaku off task siswa melalui guru mata pelajaran. DBC merupakan pemberian konsultasi dengan metode direct yang berfokus pemodelan dan pelatihan pada konsulti. Konselor selaku konsultan melakukan pengamatan secara langsung terhadap target perilaku, konselor bersama guru menganalisis target perilaku, membuat rencana intervensi terhadap siswa, konselor melatih guru dalam melakukan intervensi, konselor melepaskan guru dalam melakukan intervensi pada target perilaku dan secara terus menerus melakukan pengamatan target perilaku. Pada proses intervensi guru akan memakai prinsip-prinsip ABA dengan benar.

Variabel kedua dalam penelitian ini adalah perilaku off task. Perilaku off task adalah perilaku siswa yang tidak mendukung proses pembelajaran. Siswa secara penuh melepaskan diri dari aktivitas belajar dengan melakukan sesuatu di luar kegitan belajar. Siswa akan mendapat label melakukan perilaku off task apabila melakukan aktivitas diluar pembelajaran dalam jangka waktu tertentu dan berulang-ulang. Perilaku off task tidak dapat ditentukan hanya dengan melihat frekuensi atau durasi saja. Jika siswa beraktivitas di luar konteks pembelajaran hanya sekali namun durasi lebih dari satu menit, maka perilaku tersebut adalah off task. Atau siswa melakukan aktivitas di luar kontek pembelajaran dengan durasi kurang dari satu menit, namun dilakukan lebih dari tiga kali maka perilaku tersebut juga dikatakan off task. Perilaku off task ini diukur dengan menggunakan perekaman durasi, frekuensi dan latensi. Dari alat ukur tersebut akan terlihat berapa durasi perilaku off task siswa dan berapa kali siswa melakukan off task. Frekuensi perilaku off task terilhat dari berapa kali siswa melakukan perilaku off task dari masing-masing sesi perilaku. Ada tiga perilaku off task yang akan diintervensi dalam penelitian ini yakni; berpindah tempat yang mengganggu pbm, menggambar yang tidak terkat dengan pembelajaran, dan mengobrol. 


\section{METODE PENELITIAN}

Penelitian ini dikategorikan sebagai penelitian eksperimen karena ada suatu perlakuan (intervensi) yang diterapkan oleh peneliti. Penelitian ini menggunakan single subject design. Menurut Cresswell (2012) Single subject design termasuk dalam penelitian quasi experimental. Peneliti mempelajari perilaku individu-individu tunggal (satu atau lebih) daripada kelompok, dengan subjek menjadi kontrol sendiri dalam experiment (Cooper, Heron, \& Heward, 1987; Neuman \& McCormick, 1995). Peneliti juga akan memiliki kesempatan untuk mengobservasi perilaku individu dari waktu kewaktu, sehingga penelitian ini menjadi lebih ideal (Cresswell, 2012: 316). Bentuk experimental ini memakai single subject design dengan model $\mathrm{ABAB}$ (withdrawal design/reversal design).

Tujuan mengadaptasi Withdrawal design adalah untuk mengontrol dan menentukan bahwa penerapan DBC telah menyebabkan terjadinya penurunan perilaku off task siswa. Menurut Cooper desain ABAB lebih baik karena mengenalkan kembali kondisi $B$ yang memungkinkan replikasi dari pengaruh intervensi, yang akan menguatkan experimental control. Design ini lebih jelas dan secara umum lebih powerful digunakan dalam desain subjek kecil untuk menunjukkan hubungan fungsional antara lingkungan dan perilaku.

Desain ini digunakan untuk mengukur perubahan perilaku sebagai pengaruh dari sebuah intervensi. Hal penting yang perlu dilakukan oleh peneliti adalah memonitor dan mendokumentasikan perilaku yang muncul (nontarget behavior) untuk mengetahui pengaruh side effect dari intervensi yang bersifat negatif (Sajwaj, Twardosz, \& Burke, 1972; Hersen, 1976). Desain ini menetapkan dua kejadian (B ke A dan A ke B), ini akan menguatkan kesimpulan yang diperoleh dengan mengontrol perilaku target melalui observasi (Barlow and Hersen, 1976). Ada empat kondisi dalam Withdrawal design, yang disimbolkan dalam A-B-A-B (Lodico, 2012).

Kondisi pertama dalam Withdrawal design adalah A. Kondisi ini disebut sebagai kondisi baseline pertama. Pada kondisi baseline pertama observer mengukur perilaku off task di mana siswa tidak diberikan intervensi apapun. Kondisi baseline adalah kondisi penilaian awal terhadap perilaku klien, yang merupakan sampel dari perilaku target. Kondisi ini dilakukan dengan
3 kali pengukuran terhadap sampel perilaku tersebut pada situasi-situasi yang berbeda. Pelaksanaan baseline pertama dilaksankan pada tanggal 14, 19, dan 21 November 2013. Pengukuran perilaku off task dilakukan melalui observasi dengan menggunanan catatan anekdot dan pengukuran durasi dan latensi. Pengukuran dihentikan apabila hasil pengukuran sudah menunjukkan hasil yang konsisten.

Selama kondisi baseline, terapis menilai seberapa jauh gap antara sampel perilaku yang ditunjukkan klien dengan perilaku perilaku target untuk menentukan level perilaku yang saat ini dimiliki klien. Pada kondisi ini, terapis juga melakukan pengamatan dan penilaian terhadap lingkungan tempat di mana klien hidup sehari-hari sehingga dapat mengumpulkan informasi mengenai faktor-faktor apa saja yang mungkin potensial mendukung atau menghambat proses modifikasi perilaku terhadap klien. Setelah diamati, terapis dapat memprediksi variabel apa saja yang perlu dikontrol untuk mencapai tujuan program modifikasi perilaku.

Peneliti mengukur/menetapkan perilaku off task siswa sampai siswa tersebut memiliki trend yang stabil (tetap). Peneliti menggunakan metode observasi inter-rather perilaku target. Observasi dilakukan oleh peneliti, mahasiswa, dan alat perekam. Mahasiswa yang melakukan observasi sebelumnya telah dilatih oleh peneliti tentang bagaimana cara melakukan perekaman. Hasil observasi antara peneliti, mahasiswa dan alat perekam akan dikorelasikan apakah terdapat kesamaan dalam mengobservasi siswa.

Kondisi kedua (B) adalah kondisi di mana guru melakukan intervensi terhadap perilaku target (perilaku off task). Ketika guru melakukan intervensi kepada siswa yang off task, peneliti bersama dengan observer 2 memonitor perilaku siswa selama melakukan intervensi. Pengukuran ini dilakukan dalam jangka waktu tertentu sampai didapatkan trend yang stabil dari perilaku siswa. Intervensi yang diberikan pada siswa berupa pemberian reinforcement berupa alat tulis. Agar penelitian ini berjalan secara natural maka peneliti mengatur pemberian intervensi. Reinforcement diberikan kepada siswa yang tidak melakukan off task.

Pada kondisi intervensi pertama di sesi awal, peneliti akan melakukan functional analysis. Bentuknya adalah uji coba intervensi kepada siswa. Jika intervensi yang diuji cobakan berhasil, maka intervensi oleh guru dilanjutkan. Namun jika tidak berhasil, maka intervensi harus segera 
diganti. Pada tahap functional analysis peneliti memberikan reinforcement berupa alat tulis. Sedangkan pada tahap intervensi oleh guru menggunakan juga menggunakna reinforcement dengan menggunakan alat tulis yang berbeda dengan peneliti. Pemeberian reinforcement bertujuan untuk meningkatkan motivasi siswa untuk melakukan on task.

Setelah siswa mampu untuk berperilaku on task siswa akan mendapat reinforcement. Reinforcement yang diberikan adalah peralatan tulis yang sebelumnya dianalisis penggunaanya. Kondisi intervensi pertama dilaksanakan selama lima kali pengukuran. Prosedur pengukuran sama seperti kondisi baseline pertama.Kondisi ini dilaksanakan pada tanggal 26, 28 November dan 3, 7, 10 Desember 2013.

Kondisi ketiga (A) adalah kondisi di mana guru menarik perlakuan dan mengukur perilaku off task siswa. Pengukuran yang dilakukan prosedurnya sama dengan penetapan baseline pertama (A). Kondisi ini dilaksanakan selama empat kali pengukuran yakni pada tanggal 12, 17, 19 Desember 2013 dan 7 Januari 2014. Hal ini dilakukan untuk mengetahui efek dari pengambilan perlakuan pada subjek terhadap perilaku off task siswa. Fungsi lain dari pengembalian kondisi baseline adalah sebagai kontrol bagi perilaku siswa. Apakah benar perubahan perilaku (penurunan perilaku off task subjek) diakibatkan karena adanya intervensi yang diberikan.

Kondisi keempat (B) adalah kondisi di mana peneliti memberikan kembali intervensi dan mengukur perilaku off task melalui observasi. Langkah-langkah sama dengan kondisi kedua. Kondisi ini dilaksanakan selama empat kali pengukuran yakni pada tanggal 9, 14, 16, dan 21 Januari 2014. Pada intervensi kedua peneliti akan lebih memvariasikan reinforcement.

Subjek penelitian adalah siswa yang diidentifikasi memiliki perilaku off task tinggi. subjek penelitian adalah tiga orang siswa kelas empat yang memiliki perilaku off task tinggi. Berikut ini adalah perilaku off task yang dilakukan oleh siswa tersebut:
Tabel Hasil observasi awal

\begin{tabular}{|l|l|}
\hline \multicolumn{1}{|c|}{ Subjek } & \multicolumn{1}{|c|}{ Perilaku off task } \\
\hline I (Hamdun) & $\begin{array}{l}\text { Frekuensi dan durasi mengobrol } \\
\text { dan menggambar saat PBM }\end{array}$ \\
\hline II (Hamdan) & $\begin{array}{l}\text { Frekuensi dan durasi mengobrol } \\
\text { dan berpindah tempat saat PBM }\end{array}$ \\
\hline $\begin{array}{l}\text { III } \\
\text { (Hamdin) }\end{array}$ & $\begin{array}{l}\text { Frekuensi dan durasi mengobrol } \\
\text { saat PBM }\end{array}$ \\
\hline
\end{tabular}

\section{HASIL PENELITIAN}

Adapun hasil oenelitian dari penelitian ini adalah sebagai berikut

Subyek 1

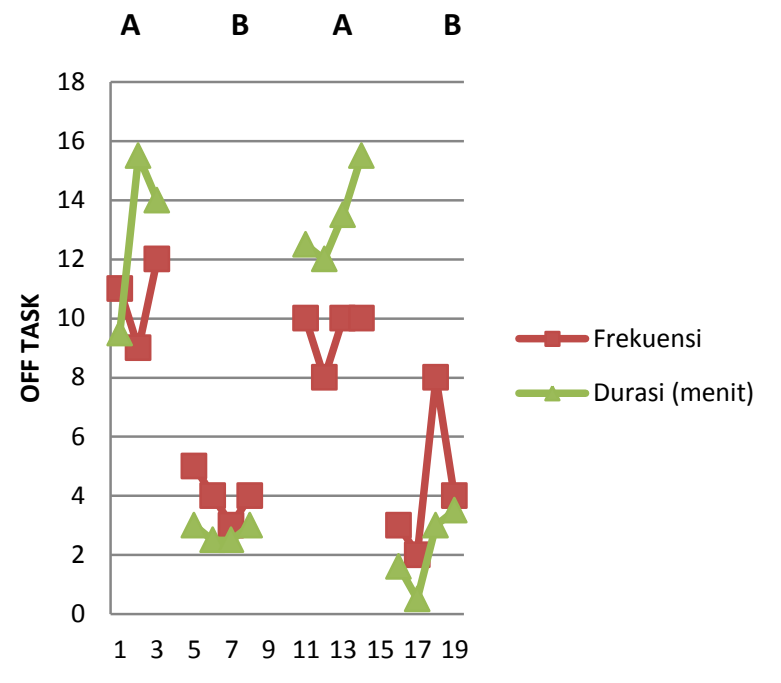

Subyek 2

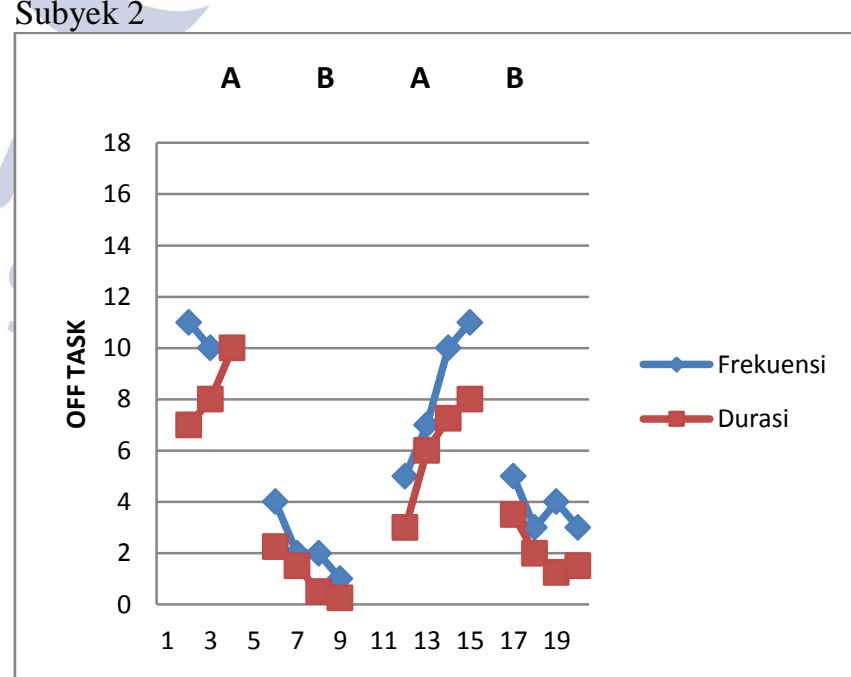




\section{PEMBAHASAN}

Subyek 3

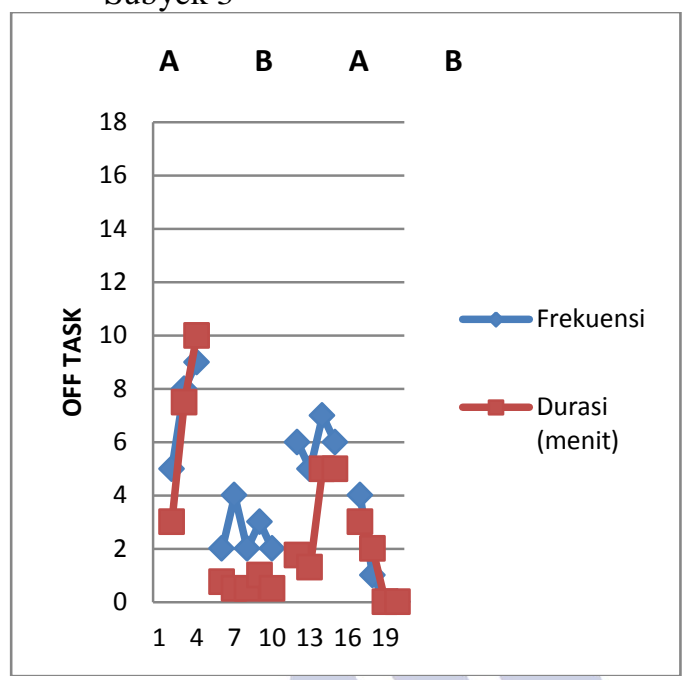

Subyek 1 pada kondisi baseline 1 dan 2 memiliki frekuensi perilaku off task antara $9 \mathrm{~s} / \mathrm{d}$ 12 dan 8 s/d 10. Sedangkan pada kondisi intervensi 1 dan 2 menurun menjadi 3 s/d 5 kali dan $2 \mathrm{~s} / \mathrm{d} 8$ kali. Subyek 2 pada kondisi baseline 1 dan 2 memiliki frekuensi perilaku off task antara $10 \mathrm{~s} / \mathrm{d} 11$ dan $5 \mathrm{~s} / \mathrm{d} 11$. Sedangkan pada kondisi intervensi 1 dan 2 menurun menjadi 1 s/d 4 kali dan $3 \mathrm{~s} / \mathrm{d} 5$ kali. Subyek 3 pada kondisi baseline 1 dan 2 memiliki frekuensi perilaku off task antara 5 s/d 9 dan 5 s/d 6 . Sedangkan pada kondisi intervensi 1 dan 2 menurun menjadi 2 s/d 4 kali dan 0 s/d 4 kali.

Subyek 1 pada kondisi baseline 1 dan 2 memiliki durasi perilaku off task antara $9.5 \mathrm{~s} / \mathrm{d} 14$ menit dan $12 \mathrm{~s} / \mathrm{d} 15.5$ menit. Sedangkan pada kondisi intervensi 1 dan 2 menurun menjadi 2.5 s/d 3 menit kali dan 0.5 s/d 3.5 menit. Subyek 2 pada kondisi baseline 1 dan 2 memiliki durasi perilaku off task antara $7 \mathrm{~s} / \mathrm{d} 10$ menit dan $3 \mathrm{~s} / \mathrm{d} 8$. Sedangkan pada kondisi intervensi 1 dan 2 menurun menjadi $0.5 \mathrm{~s} / \mathrm{d} 2.25$ menit kali dan 1.5 s/d 3.5 menit. Subyek 3 pada kondisi baseline 1 dan 2 memiliki durasi perilaku off task antara 3 s/d 10 menit dan $1.3 \mathrm{~s} / \mathrm{d} 5$. Sedangkan pada kondisi intervensi 1 dan 2 menurun menjadi 0.5 s/d 1 menit kali dan 0 s/d 3 menit.
Peran konselor dalam mengurangi perilaku off task dengan memakai pihak ketiga (guru), dapat dilakukan dengan melakukan konsultasi. Layanan konsultasi yang diberikan oleh konselor kepada guru bertujuan untuk membantu guru dalam menangani masalah siswa. Konselor membantu dengan memberikan pengetahuan dan keterampilan kepada guru untuk mengurangi perilaku off task. Proses konsultasi yang dilakukan secara behavioristik disebut DBC (Direct Behavioral Consulation).

DBC merupakan suatu metode yang secara empiris didasarkan pada metode mengajarkan keterampilan pada konsulti (Watson, Robinson: 1996). DBC bertujuan memberdayakan guru melalui konsultasi. DBC bertujuan membantu konsulti (guru) dalam menanani masalah dan memberikan keterampilan pada guru untuk menangani masalah dimasa mendatang (Watson \& Robinson, 1996; Rahn. et al, 2008: 22). Pemberian konsultasi bersifat langsung artinya dalam menentukan bentuk intevensi, konsultan tidak hanya berpatokan pada informasi masalah siswa yang diperoleh dari konsulti (guru) tetapi juga bertolak pada pengamatan langsung tingkah laku konseli (Witt, Gresham \& Noel, 1996).

Penelitian yang dilakukan oleh peneliti menghasilkan pengaruh yang berbeda pada masing-masing subjek (lihat pada grafik di bab IV). Berdasarkan hasil penelitian yang telah disajikan pada bab IV terdapat sebuah fakta. Bahwa perilaku off task relatif memiliki durasi rendah pada kondisi intervensi 1 dan 2. Observasi dilaksanakan selama 20 menit pada masingmasing sesi yang terbagi dalam $2 \times$ observasi. Observasi pertama dilaksanakan selama 10 menit di awal proses pembelajaran dan observasi kedua dilaksanakan 10 menit di akhir proses pembelajaran.

Setiap subjek memiliki respon yang berbeda. Perbedaan durasi perilaku off task disebabkan ketidak mampuan siswa mengikuti proses pembelajaran yang dilaksanakan. Menurut Fornes (2001) bahwa anak yang mengalami kesulitan belajar membutuhkan perlakuan khusus agar mereka mampu mengikuti proses pembelajaran dengan baik. Dari tiga subjek penelitian ada salah satu subjek penelitian yang mengalami kesulitas belajar. Subjek 2 memiliki kesulitasn dalam membaca, menulis dan memahami kalimat. Subjek 2 melakukan perilaku 
off task lebih lama dibandingkan dengan subjek 1 dan 3. Perilaku ini dipicu kurangmengertinya subjek dengan apa yang diterangkan oleh guru. Guru harus lebih banyak mengontrol dan memastikan bahwa subjek 2 mengerti apa yang harus ia lakukan.

Subjek 1 dan 3 tidak memiliki kesulitan dalam belajar. Subjek 1 akan melakukan perilaku off task ketika ada kesempatan untuk melakukan. Kesempatan muncul ketika guru sibuk menulis di papan tulis tanpa memperhatikan siswa, guru sibuk menerangkan dengan volume rendah dan kurang menarik perhatian siswa, Guru memberikan tugas tanpa megontrol apakah siswa benar-benar melakukan tugas atau siswa sibuk bukan mengerjakan tugas tetapi mengerjakan yang lain (menggambar, mencoret-coret bangku). Menurut Slavin (2009) Salah satu prinsip terpenting psikologi pendidikan adalah guru tidak dapat hanya memberikan pembelajaran kepada siswa.

Berdasarkan data tersebut diketahui bahwa pada kondisi baseline perilaku off task siswa tinggi dan menurun pada kondisi intervensi. Pemberian treatment yang tepat menghasilkan perilaku sesuai yang kita inginkan (Taylor \& Miller, 1997). Pemberian reinforcement jika perilaku off task siswa menurun membuat siswa termotivasi untuk tidak melakukan perilaku off task.

Setelah siswa mampu mengurangi perilaku off task siswa akan mendapat sebuah konsekuensi yang menyenangkan dengan diberikan alat tulis sebagai bentuk dari reinforcement. Pemberian reinforcement menjadi konsekuensi menyenangkan dari perilaku on task siswa, sehingga siswa akan berperilaku on task di hari berikutnya. "Reinforcer yang kuat adalah salah satu penguat di mana anak akan menunjukkan kecenderungan yang kuat. Sedangkan reinforcer yang lemah adalah yang memiliki sedikit sekali perbedaan perilaku yang ditunjukkan oleh anak" (Schloss \& Smith, 1994). Salah satu ketepatan intervensi adalah memilih bentuk reinforce yang tepat. Pada subjek 1 pada kondisi intervensi 2 memiliki frekuensi perilaku off task sebanyak $9 \mathrm{x}$ hanya turun satu level dari kondisi baseline 2. Hal ini disebabkan karena subjek 1 merasa bosan dengan reinfocer berupa pensil dan penghapus yang sudah beberapa kali diberikan.

Selain mengobservasi frekuensi dan durasi peneliti juga mengobservasi variabelvariabel yang mempengaruhi perilaku off task.
Dari data penelitian Ada beberapa hal yang memicu timbulnya perilaku off task siswa yakni: (1) teman sebangku yang mau diganggu dan dapat menggangu subjek, (2) subjek tidak mampu mengerjakan tugas yang diberikan oleh guru, (3) metode pembelajaran guru, (4) melihat atau mengetahui teman di kelas lain yang sudah beristirahat atau pulang lebih dulu, (5) guru kurang mengontrol perilaku siswa, (6) berkurangnya makna reiforcement bagi subjek.

Selama penelitian peneliti juga melakukan observasi dan wawancara dengan guru dan tetangga subjek 1. Berikut adalah beberapa data yang didapat selama penelitian. Pada subjek 1 kondisi rumahnya yang selalu sepi dan selalu ditinggal sendiri tanpa ada pengawasan dari orang tua kemungkinan membuat subjek 1 lebih banyak menyibukkan diri di dalam kelas (hal ini perlu dilakukan penelitian lanjutan). Kondisi ekonomi keluarga yang berkecukupan juga mempengaruhi kebermaknaan reinforcement yang diberikan yakni berupa pensil, penghapus, dan orotan). Terlihat pada kondisi intervensi kedua pada sesi ketiga frekuensi perilaku off task subeyk 1 meningkat. Sehingga pada sesi keempat guru lebih banyak mengontrol perilaku tersebut. Hal itu menandakan bahwa penggunaan reinforcement harus dilakukan secara cermat. Efektivitas program penguatan ditingkatkan dengan mendorong siswa berpartisipasi selama pelaksanaan dan implementasi (Schloss \& Smith, 1994). Siswa juga perlu dikontrol agar dengan memberikan perhatian dan sesekali mengingatkan siswa tentang cerita metaforik yang diberikan.

Subjek 1 merasa bahwa reinforcement yang diberikan tidak lagi menarik. Berkurangnya makna reinforcement memang tidak terjadi pada subjek 2 dan 3. Standar untuk intervensi analisa kebiasaan terapan yang efektif dapat dicapai hanya dengan melalui perencanaan yang hati-hati (Baer, Wolf \& Riley, 1987; Schloss \& Smith, 1994). Martin dan Pear (1988) Telah menyarankan beberapa aturan umum untuk meningkatkan perubahan perilaku. Mereka adalah sebagai berikut:

1. Pilih program yang berguna bagi siswa. Mereka kemungkinan besar akan dilakukan oleh anak atau remaja di luar program intervensi formal.

2. Melakukan intervensi dalam pengaturan alam. Ketika perubahan diharapkan dalam beberapa pengaturan, counduct intervensi dalam setiap pengaturan yang relevan. 
3. Variasikan kondisi di mana perilaku yang diinginkan diharapkan terjadi untuk membantu siswa dalam mentransfer ke situasi tidak serupa.

4. Ketika awalnya pemrograman untuk perubahan perilaku dalam pengaturan baru, mungkin perlu untuk menggunakan jadwal artifisial penguatan. Secara bertahap mengurangi jadwal penguatan sekali tanggapan sesuai jika terjadi konsisten sampai macthes atau lebih ramping daripada jadwal penguatan ditemukan dalam pengaturan alam.

Subjek 2 memiliki keterbatasan dalam belajar. Kondisinya yang belum bisa membaca dengan lancar dan tidak bisa membuat satu kalimat utuh membuat subjek 2 selalu melakuakn off task ketika guru memberikan tugas yang ia tidak mampu mengerjakan. Dari hasil pengamatan dan diskusi dengan para guru subjek 2 mengalami kesulitan belajar. Bauer, Keefe \& Shea (2001) menjelaskan bahwa "kesulitan belajar adalah peristilahan yang dipergunakna pada siswa-siswa yang mempunyai kesulitan tidak dapat mengikuti kegiatan belajar mengajar karena kurangnya intelegensi kelainan sensoris, ketidakberuntungan atau ketidakcukupan budaya atau bahasa". Banyak anak-anak dengan kesulitan belajar memiliki kesulitan dalam mengerjakna tugas-tugas sekolah. Mereka mempunyai masalah dengan menulis, memabaca, dan berhitung. Memang terlalu dini jika menyebutkan bahwa subjek 2 mengalami kesulitan dalam belajarnya namun, para guru juga harus memperhatikan dan memberikan pembelajaran secara khusus untuk subjek 2 sesuai dengan potensinya.

Subjek 3 memiliki potensi yang bagus di bidang akademis. Anak yang tidak banyak ulah dan jarang menjaili teman di dalam kelas. Subjek 3 memiliki teman akrab di dalam kelas yang berinisial Ris. Jika subjek 2 dan Ris berada dalam satu bangku, maka dua sahabat ini akan asyik bermain dan ngobrol dan seringkali mengabaikan guru yang sedang menerangkan. (Santrock, 2003: 219) salah satu fungsi teman sebaya adalah menyediakan berbagai informasi mengenai dunia diluar keluarga. Kedekatan teman sebaya yang intensif akan membentuk suatu kelompok yang dijalin erat dan tergantung antara satu sama lainnya, dengan demikian relasi yang baik antara teman sebaya penting bagi perkembangan sosial yang normal.

Metode pembelajaran yang dipakai guru juga turut mendukung perilaku siswa di dalam kelas. Soekartawi (2005) menjelaskan bahwa "cara mengajar yang baik dan benar adalah cara mengajar yang dapat di praktekkan dan menghasilkan keluaran seperti yang diharapkan". Berdasarkan hasil observasi selama penelitian yang dilakukan peneliti ketika guru berceramah siswa lebih banyak melakukan off task. Sebaliknya ketika guru memberikan tugas mencatat atau mengerjakan soal yang dibatasi waktu siswa lebih banyak diam. Beberapa riset yang diungkapkan dalam buku Partin (2009) menyatakan bahwa orang belajar melalui indera dan persepsi mereka. Persepsi tidak hanya mensuplai sebagian besar apa yang kita ingat. Namun juga menghubungkan pada kejadian yang kita ingat. Walaupun sesungguhnya sebagian besar orang orang belajar melalui pengindraan.

Belajar tidak hanya menerima informasi dari pengajar, tetapi juga proses membangun makna/pemahaman terhadap informasi dan/atau pengalaman. Belajar bukanlah proses menerima ceramah materi dari guru, melainkan pemahaman dan internalisasi materi sehingga memunculkan kebermaknaan. Kebermaknaan itu terlihat dari balikan yang siswa baik dalam konteks proses belajar, dalam ujian, maupun dalam kehidupan nyata. Apabila siswa memberikan respon terhadap teori di dalam kelas, misalnya, maka proses belajar bermakna telah dimulai. Apabila siswa mampu menjawab soal-soal ujian dengan tepat, kebermaknaan lanjutan juga telah terjadi. Apabila siswa mampu melaksanakan aplikasi dari apa yang dipelajari di dalam kelas, maka akan terjadi sebuah kebermaknaan yang sempurna.

Kegiatan belajar mengajar tidak selalu harus terjadi di dalam ruangan, tetapi juga di luar ruangan. Tugas guru adalah menyediakan pengalaman belajar yang beragam pada kedua tempat itu agar siswa memperoleh pengalaman belajar yang bermakna, yaitu yang tingkat pencapaiannya $90 \%$ s/d $100 \%$ seperti pada gambar 5.1.

Faktor lain yang menyebabkan terjadinya perilaku off task adalah melihat teman di kelas lain telah istirahat atau pulang lebih dulu. Siswa akan lebih banyak melakukan perilaku off task ketika mereka melihat ataupun mendengarkan ada teman di kelas lain yang sudah mendapat waktu istirahat atau pulang lebih dulu. Bandura menyatakan bahwa manusia belajar dengan mengamati apa yang dilakukan oleh orang lain. Melalui belajar mengamati (disebut modeling atau imitasi)manusia secara kognitif menampilkan perilaku orang lain kemudian mengadopsi 
perilaku tersebut. Begitu pula yang dilakukan oleh siswa. Ketika melihat teman di kelas lain mendapatkan kesempatan waktu istirahat atau pulang lebih dulu, maka mereka cenderung ingin melakukan hal yang serupa.

Selain itu, Guru kurang mengontrol perilaku siswa. ketika guru memakai metode berceramah dan tetap dalam satu tempat (berdiri di dedapn salah satu siswa) ,maka siswa yang terletak lebih jauh dari guru akan lebih banyak melakukan off task dbanding siswa yang berada dekat dengan guru. Partin menjelaskan dalam bukunya bahwa kita tidak mungkin mengharapkan seluruh siswa tetap diam terpaku di tempat duduk, terpengaruh oleh pengajaran yang begitu hebat. Namun guru memiliki keterampilan besar saat mengajar. Guru yang terampil mampu menarik perhatian siswa yang akan berdampak pada pencapaian prestasi siswa di sekolah (Partin, 2009).

Sebagai salah satu model pemecahan masalah siswa, DBC menjadi solusi bagi ketiadaan konselor atau psikolog di MI. Pelaksanaan DBC yang sifatnya langsung/direct membuat konsultan dapat mengamati secara langsung perilaku siswa. Sifat langsung memudahkan konsultan melakukan kontak langsung dengan siswa dan tidak hanya melalui konsulti/ guru, meskipun pada akhirnya konsulti diharapkan mandiri menangani masalah siswa. Model DBC juga membantu guru untuk memperbaiki perlakuan guru terhadap siswa yang melakukan off task. Proses konsultasi memberikan informasi kepada guru untuk memahami antecendent dan konsekuensi terhadap kemunculan perilaku siswa. Sehingga guru dapat menentukan perlakuan untuk menangani masalah tersebut. Contoh; sebelum peneliti melakukan penelitian salah seorang guru di MI saat PBM fakta hanya memperhatikan subjek 2 karena ia tidak bisa mengerjakan tugas. Sikap guru tesebut bertujuan agar subjek 2 mangerjakan tugas. Namun, disisi lain kelas menajdi lebih gaduh karena siswa yang lain melkaukan off task dan subjek menjadi ketergantungan kepada guru ketika diberikan tugas. Karena guru selalu membantu subjek 2 saat ia tidak ramai dan tidak mengerjakan tugas. Guru yang lain hanya berceramah dan akan marah/memangil siswa off task. Memanggil siswa bertujuan agar siswa diam dan kembali memperhatikan. Namun guru tidak tahu bahwa dengan memanggil nama siswa off task, siswa akan diam sejenak dan kembali off task ketika guru kembali menerangkan). DBC membantu guru untuk menyadari akan kesalahan dalam prosedur perlakuan masalah siswa.

\section{DAFTAR PUSTAKA}

Bauer, D. R,. Keete, C.H., and Shea, T. M. (2001). Student With Learning Disabilities or Emotional and Behavior Disorder, Upper Saddle River, NJ: Merril.

Creswell, J.W. (2012). Educational Reasearch Planning, Conducting, And Evaluating And Qualitative Reasearch. USA: Pearson

Depdiknas. (2008). Kurikulum Tingkat Satuan Pendidikan. Jakarta: Dikmenum. Depdiknas.

Cooper, J,. Heron, T.E,. And Heward, W.L., (2007). Applied Behavior Analysis $\left(2^{\text {nd }}\right)$. Upper Saddle River, NJ: Prentice-Hall.

Martin, G. \& Pear, J. (2011). Behavior Modification What It Is and How To Do It (Ninth edition). USA: Pearson.

Partin, R.L. (2009). Kiat Nyaman Belajat di dalam kelas.Jakarta: PT. Indeks.

Lodico, M.G et all. (2006). Methods in Educational Research. San Fransisco: Jossey-Bass.

Rahn. E.J,. (2008). The effects of direct and indirect school consultation Methods on teacher treatment integrity and student behavior Change in a general education setting. United State: UMI.

Santrock, J.W. (2003). Life Span Developmental-Perkambangan Masa Hidup (edisi kelima). Jakarta: Penerbit Erlangga.

Schloss, P.J. \& Smith, M.A. (1994). Applied Behavior Analysis in the Classroom. Boston: Allyn and Bacon

Soekartini.(2005). Meningktakan Efektivitas Mengajar. Jakarta; Radar Jaya Offset.

Snow, M.S. et al,. (2004), Creative Metaphors of Life Experiences Seen in Play, Vol 12 (1), 63-65.

Slavin, R. E., (2009). Psikologi Pendidikan Teori dan Praktik jilid 2 (8 ed). Jakarta: Indeks. 
Taylor, J \& Miller, M,. (1997). Treatment Integrity and Functional Assesment. School Psychology Quarterly. 12 (1). 13.

Witt, J. C,. Gresham, F.M. \& Noell, G.H. (1996). What behavior about behavioral consultation? Journal of educational and psychological consultation, Vol 7(4), 327-344.

Witztum, M. et al,. (1988), The Use of Metaphors in Psychotherapy, hal 1-11.

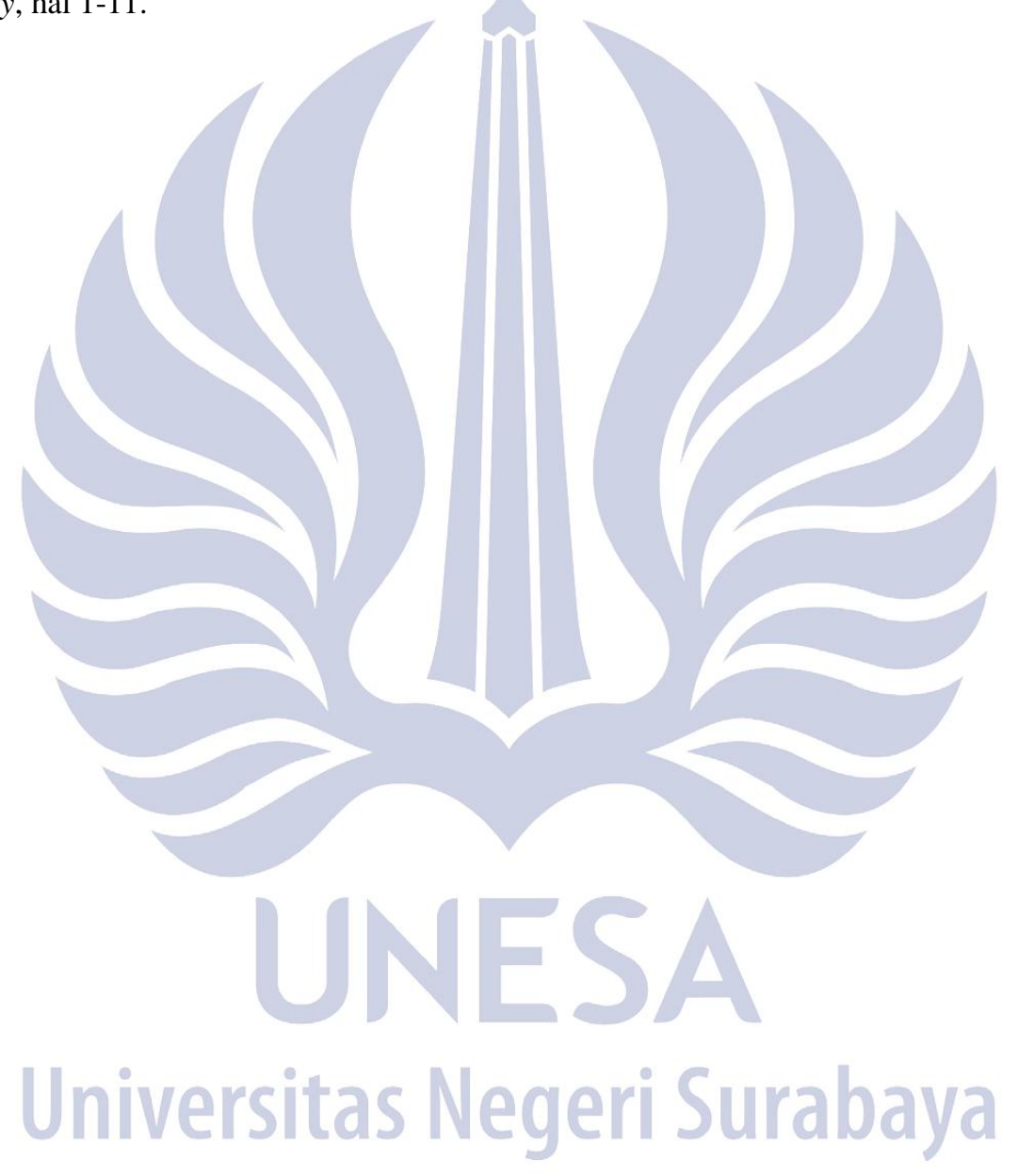

